\title{
Residual Effects of Ethylene on Tulip Growth and Flowering
}

\author{
Christopher B. Cerveny and William B. Miller ${ }^{1}$ \\ Department of Horticulture, Cornell University, 28 Plant Science Building, \\ Ithaca, NY 14853
}

Additional index words. Tulipa gesneriana, 1-methylcyclopropene, 1-MCP, EthylBloc ${ }^{\mathrm{TM}}$ sachet, hydroponics

\begin{abstract}
Ethylene effects were investigated on two tulip (Tulipa gesneriana L.) cultivars, Markant and Carreria. Pre-cooled bulbs were treated with ethylene (flow-through) for 1 week at $0,0.1,1.0$, or $10 \mu L \cdot L^{-1}( \pm 10 \%)$ in a modified hydroponic system. After ethylene exposure, plants were either destructively harvested for root measurements or forced in a greenhouse for flower measurements. Ethylene exposure at concentrations as low as $1 \mu \mathrm{L} \cdot \mathrm{L}^{-1}$ during the first week of growth reduced shoot and root elongation and subsequently increased flower bud abortion. At $10 \mu \mathrm{L} \cdot \mathrm{L}^{-1}$, root growth was essentially eliminated. In a second experiment, bulbs were treated overnight with 1-methylcyclopropene (1-MCP) before a 7-day exposure to $1 \mu \mathrm{L} \cdot \mathrm{L}^{-1}$ ethylene. 1-MCP pretreatment eliminated the harmful effects of ethylene on root and shoot growth. This study illustrates the effects of ethylene exposure during hydroponic tulip production and demonstrates a potential benefit to treating bulbs with 1-MCP before planting.
\end{abstract}

Tulip (Tulipa gesneriana L.) is an ornamental geophyte prized for centuries as a cut flower, potted plant, and garden favorite. Tulip bulbs are grown in fields and sold to specialized producers who "force" the plants into flower after a cold treatment of 12 or more weeks. In cut flower tulip production, bulbs are often forced in hydroponic systems that facilitate flower harvesting. With hydroponic forcing, tulip bulbs are given $\approx 80 \%$ to $85 \%$ of their required cold duration before "planting" in water or a dilute nutrient solution and then further cooled 1 to 3 weeks to complete the cold requirement (De Hertogh, 1996). This process allows a minimal level of root establishment before forcing at warmer temperatures.

During tulip bulb development and storage before cooling, ethylene can cause a number of physiological and morphological disorders, including gummosis (excretion of polysaccharides), flower bud abortion, shortened leaves or flowers, reduced or eliminated roots, deformed anthers, abnormal growth habit, loss of fresh weight during storage, and excessive growth of daughter bulbs (splitting) (Kamerbeek and de Munk, 1976). The degree of ethylene damage depends on a number of factors, including concentration, duration (De Munk, 1972), temperature during exposure (De Munk,

Received for publication 24 Mar. 2010. Accepted for publication 5 June 2010.

We thank Anthos, Hillegom, The Netherlands, for plant materials and funding support, and Floralife, Inc. for the donation of EthylBloc ${ }^{\mathrm{TM}}$ sachets (1-MCP). Appreciation is also expressed to The Cornell Statistical Consulting Unit for advice on data analysis and to Simon Laan and Joanna Blaszczak for their greenhouse expertise and assistance with data collection, respectively.

${ }^{1}$ To whom reprint requests should be addressed; e-mailwbm8@cornell.edu.
1973), and tulip cultivar (Miller et al., 2004; De Wild et al., 2002). A significant source of ethylene in the tulip industry is the fungal pathogen fusarium (Fusarium oxysporum Schlecht f. sp. tulipae), which produces ethylene when colonizing tulip bulbs (Kamerbeek and de Munk, 1976). These fungal infections therefore create a unique production challenge for cut flower tulip growers given the potential for ethylene exposure to actively growing roots and shoots.

1-Methylcyclopropene (1-MCP) is widely used in postharvest horticulture, gaining popularity for ornamental plants as an ethylene perception inhibitor that blocks ethylene binding sites in plant tissue (Blankenship and Dole, 2003; Watkins, 2006), thus protecting the tissue against ethylene damage for variable periods (Sisler and Serek, 1997). Gude and Dijkema (2005) demonstrated protection from ethylene damage in tulip storage by $24 \mathrm{~h} 1$ MCP applications $\left(0.2 \mu \mathrm{L} \cdot \mathrm{L}^{-1}\right)$ at $12-\mathrm{d}$ intervals. The potential for 1-MCP application immediately before planting has not been investigated and is the subject of this research.

\section{Materials and Methods}

Pre-cooled bulbs $\left(16\right.$ weeks at $\left.5{ }^{\circ} \mathrm{C}\right)$ of Tulipa gesneriana L. 'Markant' were treated with flow-through ethylene at nominal concentrations of $0,0.1,1.0$, or $10 \mu \mathrm{L} \cdot \mathrm{L}^{-1}( \pm$ $10 \%$ ) for 1 week at $20{ }^{\circ} \mathrm{C}$ in a modified hydroponic system. Bulbs were impaled on a grid of plastic spikes, $\approx 1.5 \mathrm{~cm}$ long, as is common in commercial hydroponic tulip production. Impaled bulbs (six subsample bulbs per three treatment replicates; $n=72$ ) were placed in $4.5-\mathrm{L}$ sealable plastic tubs with tap water $(1.5 \mathrm{~L})$ added to $1 \mathrm{~cm}$ above the bulb basal plate. Each container was plumbed independently for flow-through air or ethylene, and treatments were administered in a completely randomized design.
Ethylene concentrations were verified by daily measurements using a Buck 310 gas chromatograph (Buck Scientific, East Norwalk, CT) fitted with an alumina column and a flame ionization detector. After 1 week of ethylene exposure, plants were destructively harvested for the following measurements: plant height (basal plate to the tip of the tallest leaf), root length (mean of three longest roots per bulb), and root fresh weight (including 1-cm basal plate). When the experiment was repeated with the same setup as previously described, instead of destructive harvest, bulbs were forced into flower in a presumed ethylene-free greenhouse, at which time stem length (basal plate to bud tip) and percent aborted flowers (plants showing no flower) were calculated. Days to flower were not calculated, but it was $\approx 10$.

To test the efficacy of 1-MCP pretreatment against ethylene damage, a second experiment was designed in which 'Carreria' bulbs were treated with 1-MCP (EthylBloc ${ }^{\mathrm{TM}}$ sachets; Floralife, Inc., Walterboro, SC) before ethylene exposure. 'Carreria' bulbs were impaled on a planting grid and placed in 4.5-L plastic tubs. One sachet per treatment container was placed in a small beaker containing $25 \mathrm{~mL}$ distilled water and then immediately enclosed with the bulbs for $24 \mathrm{~h}$ at $20{ }^{\circ} \mathrm{C}$. Control bulbs were similarly sealed in a separate container without $1-\mathrm{MCP}$. The containers were then opened, beakers were removed, 1.5 $\mathrm{L}$ tap water was added, and then resealed for ethylene exposure at 0 or 1 $\mu \mathrm{L} \cdot \mathrm{L}^{-1}( \pm 10 \%)$ in the same hydroponic system as described previously. This experiment also included three replicates of six bulbs per treatment. After 1 week, plants were destructively harvested for the same root and shoot measurements described previously.

All data were subjected to analysis of variance using standard least squares in JMP (SAS Institute, Cary, NC) with regression analysis or a means separation procedure (Tukey's honestly significant difference) where appropriate. Using a natural $\log (\ln )$ transformed ethylene concentration provided the best fit for the regression analysis; thus, all values were transformed on the basis of $\ln$ (ethylene concentration +0.1 ) (because $\ln 0$ is undefined). Analysis of variance and means separation for experiments using 1MCP were calculated using non-transformed data.

\section{Results and Discussion}

Ethylene inhibited root length at concentrations as low as $0.1 \mu \mathrm{L} \cdot \mathrm{L}^{-1}$, and as concentration increased, root length decreased exponentially (Fig. 1). Plant height and root fresh weight decreased linearly as ethylene concentration increased (Fig. 1). By the conclusion of ethylene exposure, virtually all outward growth was stunted from 10 $\mu \mathrm{L} \cdot \mathrm{L}^{-1}$ ethylene, especially with regard to rooting (Figs. 1 and 2). At flowering, although some of the initial stunting was recovered, stem length remained strongly influenced by 


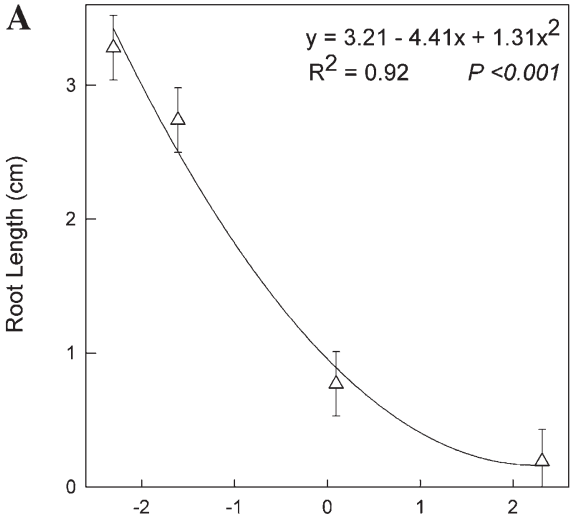

Ln (Ethylene Conc. + 0.1)
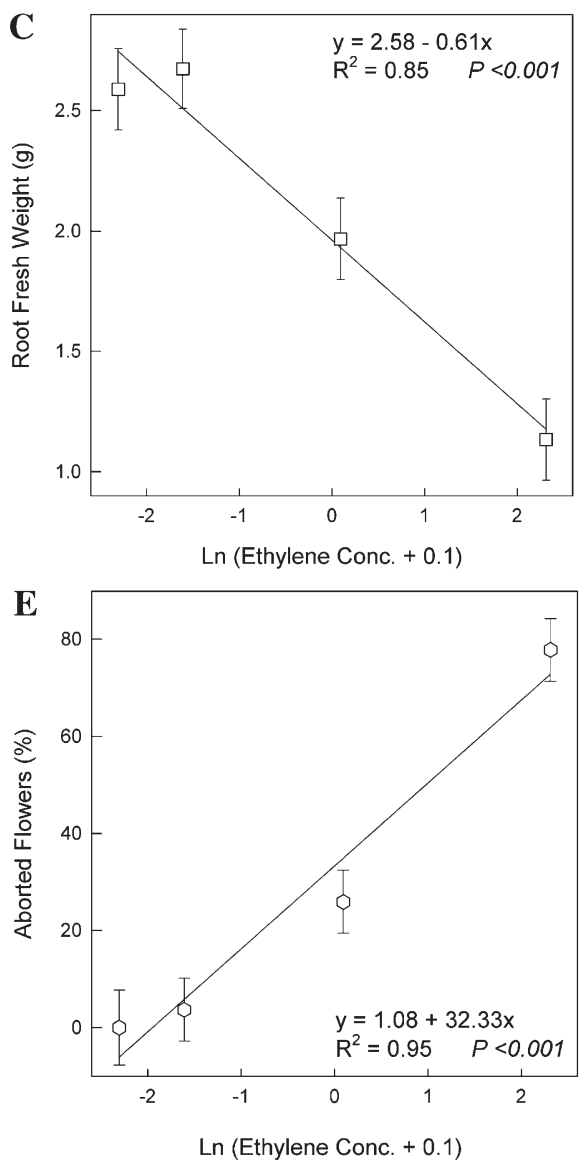

Fig. 1. Influence of flow-through ethylene at 0 to $10 \mu \mathrm{L} \cdot \mathrm{L}^{-1}$, transformed: $\ln$ (ethylene concentration +0.1 ), provided to Tulipa gesneriana 'Markant' for 1 week at $20^{\circ} \mathrm{C}$ in the hydroponic growing environment. Data were collected from two experiments. In the first experiment, root length (mean of three longest roots per plant), plant height (basal plate to longest leaf), and root fresh weight (including 1-cm basal plate) were collected on removal from ethylene exposure (A-C, respectively). In the second experiment, stem length at flower (basal plate to flower tip) and percent aborted flowers (D-E, respectively) were collected after forcing in a presumed ethylene-free greenhouse. Data are means $( \pm \mathrm{SE})$.

previous ethylene exposure as did flower bud abortion, respectively, decreasing or increasing linearly as ethylene concentration increased (Figs. 1 and 2).

Our results are consistent with those published by De Munk and de Rooy (1971), in which they measured ethylene effects on tulip growth by planting fusarium-infected bulbs alongside healthy tulips in soil culture. Although our experiments were conducted in a modified hydroponic system, the ethylene-
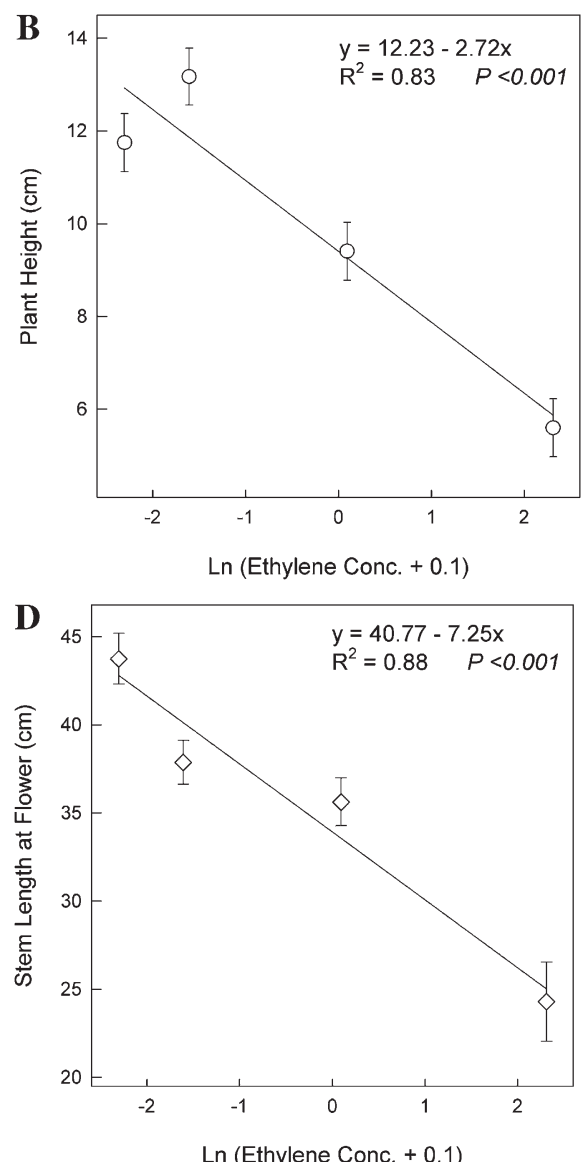

Ln (Ethylene Conc. + 0.1)

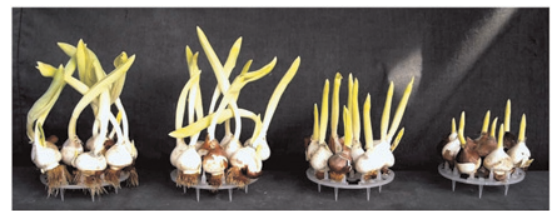

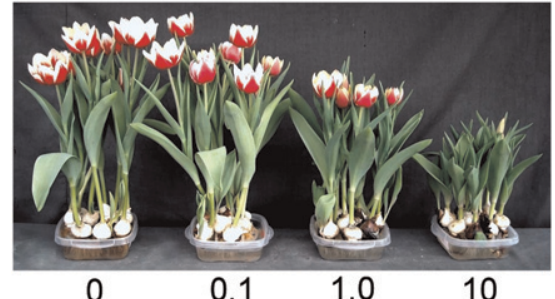

Ethylene concentration $(\mu \mathrm{L} / \mathrm{L})$

Fig. 2. Influence of flow-through ethylene ( 0 to 10 $\mu \mathrm{L} \cdot \mathrm{L}^{-1}$ ) provided for 1 week at $20{ }^{\circ} \mathrm{C}$ during rooting of hydroponically grown Tulipa gesneriana 'Markant'. Flowering plants were subsequently forced in an ethylene-free greenhouse. (Top) Plants immediately after conclusion of ethylene treatment; (bottom) at flowering.

Table 1. Effect of 1-MCP treatment before 1.0 $\mu \mathrm{L} \cdot \mathrm{L}^{-1}$ ethylene exposure on plant height (basal plate to longest leaf) and root length (mean of three longest roots per bulb) of Tulipa gesneriana 'Carreria'.

\begin{tabular}{lcc}
\hline Treatment & Plant ht $(\mathrm{cm})$ & Root length $(\mathrm{cm})$ \\
\hline +MCP + Eth & $18.5 \mathrm{a}^{\mathrm{y}}$ & $3.6 \mathrm{a}$ \\
+MCP - Eth & $16.1 \mathrm{~b}$ & $3.8 \mathrm{a}$ \\
-MCP -Eth & $15.9 \mathrm{~b}$ & $3.4 \mathrm{a}$ \\
-MCP + Eth & $9.1 \mathrm{c}$ & $1.7 \mathrm{~b}$ \\
& & \\
Source & $* * *$ & $* * *$ \\
MCP (M) & $* * *$ & $* * *$ \\
Ethylene (E) & $* * *$ & $* * *$ \\
M $\times$ E &
\end{tabular}

${ }^{\mathrm{z}}$ Bulbs were exposed to ethylene for 1 week at $20{ }^{\circ} \mathrm{C}$ while in the growing environment.

${ }^{y}$ Means in columns not followed by the same letter are different at $\alpha=0.05$.

*** Significant at $P \leq 0.0001$.

1-MCP $=1$-methylcyclopropene.

a commercial greenhouse. De Munk (1971) measured ethylene levels as high as $22 \mu \mathrm{L} \cdot \mathrm{L}^{-1}$ from enclosed fusarium-infected tulip bulbs; therefore, severe damage caused by our $10-\mu \mathrm{L} \cdot \mathrm{L}^{-1}$ treatment is entirely plausible in a commercial production system where fusarium-infected tulip bulbs are present.

Deleterious effects of $1 \mu \mathrm{L} \cdot \mathrm{L}^{-1}$ ethylene were essentially eliminated with 1-MCP pretreatment (Table 1; Fig. 3). The only exception was with root fresh weight, in which the interaction between 1-MCP and ethylene was nonsignificant. However, the main effects for these data support a similar trend, heavier root mass with 1-MCP treatment than without (3.2 versus $2.7 \mathrm{~g}$, respectively) and lighter root mass with ethylene exposure regardless of 1-MCP treatment (data not shown). In tulip, 1-MCP treatment was previously shown to provide protection from various forms of ethylene damage for up to $12 \mathrm{~d}$ after application (Gude and Dijkema, 2005). This is consistent with our data, which indicate 1MCP was effective at reducing ethylene injury for at least 1 week in the earliest phases 


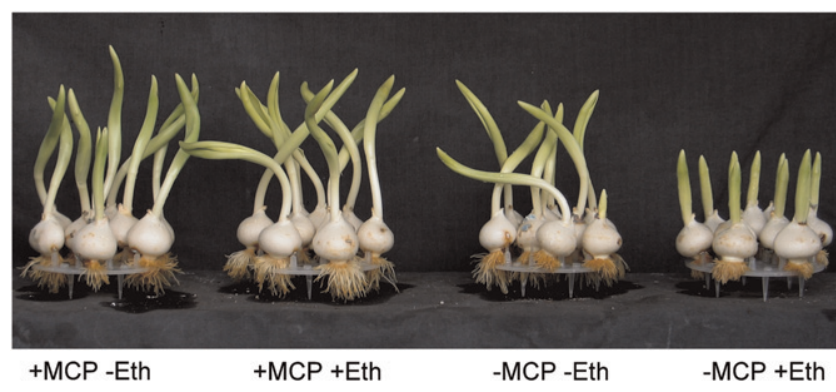

Fig. 3. Influence of 1-methylcyclopropene treatment (a single Ethylbloc sachet ${ }^{\mathrm{TM}}$ dipped in water) for $24 \mathrm{~h}$ at $20{ }^{\circ} \mathrm{C}$ before $1.0 \mu \mathrm{L} \cdot \mathrm{L}^{-1}$ ethylene exposure $\left(1\right.$ week at $\left.20^{\circ} \mathrm{C}\right)$. Photograph taken at conclusion of ethylene treatment.

of growth and establishment in the greenhouse.

\section{Literature Cited}

Blankenship, S.M. and J.M. Dole. 2003. 1methylcyclopropene: A review. Postharvest Biol. Technol. 28:1-24.

De Hertogh, A.A. 1996. Holland bulb forcer's guide, 5th Ed. Alkemade Printing BV, Lisse, The Netherlands.
De Munk, W.J. 1971. Bud necrosis, a storage disease of tulips. II. Analysis of disease-promoting storage conditions. Neth. J. PI. Path. 77:177186.

De Munk, W.J. 1972. Bud necrosis, a storage disease of tulips. III. The influence of ethylene and mites. Neth. J. Plant Pathol. 78:168178.

De Munk, W.J. 1973. Flower-bud blasting in tulips caused by ethylene. Neth. J. Pl. Path 79:41-53.
De Munk, W.J. and W. de Rooy. 1971. The influence of ethylene on $5 \mathrm{C}$ precooled 'Apeldoorn' tulips during forcing. HortScience 6:4041.

De Wild, H.P.J., H.W. Peppelenbos, M.H.G.E. Dijkema, and H. Gude. 2002. Defining safe ethylene levels for long term storage of tulip bulbs. Acta Hort. 570:171-175.

Gude, H. and M. Dijkema. 2005. The use of 1-MCP as an inhibitor of ethylene action in tulip bulbs under laboratory and practical conditions. Acta Hort. 673:243-247.

Kamerbeek, G.A. and W.J. de Munk. 1976. A review of ethylene effects in bulbous plants. Sci. Hort. 4:101-115.

King, J.A. and K.A. Smith. 1987. Gaseous diffusion through peat. J. Soil Sci. 38:173-177.

Miller, W.B., M. Verlouw, S.S. Liou, H.O. Cirri, C.B. Watkins, and K. Snover-Clift. 2004. Variation in fusarium-induced ethylene production among tulip cultivars. Acta Hort. 673:229-235.

Sisler, E.C. and M. Serek. 1997. Inhibitors of ethylene responses in plants at the receptor level: Recent developments. Physiol. Plant. 100:577-582.

Watkins, C.B. 2006. The use of 1-methylcyclopropene (1-MCP) on fruits and vegetables. BioTech Adv. 24:389-409. 